\title{
THE RIGHTNESS OF PRINCIPLES AS THE CONCEPT OF THE GOOD
}

\begin{abstract}
This paper concerns the twilight of the concept of the common good and the rise of the idea of rightness over the conceptions of the good. J. Rawls differentiates between the extensive doctrines under which various conceptions of the good are formulated and the principles of justice, which deliberately avoiding the issue of good, stop at the level of what is right. The rightness allows for pluralism of various broad doctrines that can last, grow and compete with one another within and under the protection of a liberal and democratic state. But we have to admit that there is no escape from the question of the good (and the bad) while considering the social and political issues being moral issues in some important sense for us. The defence of the principles of justice by means of pointing out their rightness and distinguishing them from various conceptions of the good is - at the level of politics and political philosophy - reasonable and purposeful (because of the values that we cherish together, as well as in order to avoid certain damages which we fear), but it is still a kind of the conception of the good. The stability of liberal society lies in the ability to promote the right conception of justice which is referred to as thin conception of the good. The normative content does not evaporate from the principles of political life, but it is retained the primary concern of the state is justice, fairness, equality, etc.
\end{abstract}

Keywords: justice, good, J. Rawls.

\section{THE TWILIGHT CONCEPT OF THE COMMON GOOD}

With regard to contemporary political philosophy there are seldom references to the good as aprinciple governing social relations, building a social structure, defining a political objective of the society. As for the political discourse, the concept of the good has been supplanted by terms such as the national interest (raison d'etat), the public interest, the public good, the common good (social, public). Sometimes the good of the community is determined by means of the rights of the citizens (e.g. the right to own property, the right to medical care, etc.), in other cases this term refers to all types of cultural products. Meanwhile, the classical philosophy of politics (since the period of Aristotle) has considered social issues referring to the concept of the common good. This concept was important for enlightenment thinkers offeringthe secular vision of human nature (Rousseau, Locke) and still it is crucial to the social doctrine of the Catholic Church these days. Likewise, modern conservative thinkers, associated with republican tradition (Oakeshott, Arendt, MacIntyre), consider the common good as a basic/fundamental factor of social life, a motive of people forming a community. This good is defined as an actual aim of the communitythat all the citizens together and

\footnotetext{
${ }^{1}$ Prof. Magdalena Żardecka-Nowak, DSc, PhD, Institute of Sociology, Rzeszow University, e-mail: magda.zardecka@gmail.com
} 
individually can identify with; as a collective value consisting of perfection and prosperityof many people achievable in mutual cooperation through the use of social facilities and resources ${ }^{2}$. In the field of politics the common good is considered to be the highest good (summumbonum).

In classical philosophy of politics opposing standpoints have been distinguished: individualism - collectivism, and elitism - egalitarianism, which determine different ways of understanding the common good. Moreover, the common good can be perceivedinstitutionally or essentially. As for the institutional and instrumental concept,the means for achieving social and political goals are accepted. The common good is seen as convenient conditions and a set of devices, institutions and facilities serving the citizens. On the other hand, essentialist concept stresses the importance of personal development and improvement of the members participating in social life due to social resources. It assumes the innate attitude of human beingsto the good and the ability of gaining and multiplying it. Owing to the natural direction towards the good, it resultsthe moral obligation to be obeyed individually and in collaboration with others. The common good is ancillary to the personal good, which can only be achieved through participation in a social life. Even the best organized society is not able to guarantee the full implementation of personal goods that are not achievable only by socio-political means as well as due to the infinite aspirations of the human spirit. However, a poorly organized society may constitute a major obstacle in a personal development of citizens. Supporters of essentialism believe that the common good is a state of perfection of the society as a whole. Its proper understanding is possible only in the context of a broader, philosophical view on the nature (essence) of the state, society, human being and morality. It is impossible to grasp its nature or its full implementation, so there is a need for constant revision of its comprehension and specification in the form of executive standards determining its proper shape. A legal state authority legitimizes itself and strengthens its function by the use of serving it. The common good includes normative content; it is a social, moral principle and a general,political principle. Its structure is tripartite: the ideal of the common good, the executive standard and the competent political authority.

Theorists distinguish three areas of the common good: 1) legal and administrative order; 2) a set of economic goods; 3) institutions of culture, education and upbringing $^{3}$.Legal and social order is the common good, because it determines the relationships between the state and citizens,implements the division between the rights and obligations that define legal and moral relationships between entities. Systems of interdependencies between citizens, institutions, associations, etc. create the overall legal and social structure of given country. A legal system is one of the most important elements of the common good, as it organizes the functioning of the entire state. Lack of such order would prevent individuals to cooperate and achieve their goals. When it comes to a set of economic goods, it is obvious that without them it is impossible to live and develop individuals or the community; they are a collection of basic /fundamental goods which are the subject of common concern. Common good means to achieve and maintain

${ }^{2}$ See J. Krucina, Dobro wspólne, in: Encyklopedia katolicka, vol. III, TN KUL, Lublin 1985, col. 1379-1382.

${ }^{3}$ See J. Koperek, Dobro wspólne, in: B. Szlachta (edit.), Stownik społeczny, WAM, Kraków 2004, pp 144-146. 
an optimal level of wealth and prosperity. Common good also includes culture, education and upbringing - a collection of spiritual, moral and intellectual values together with all institutionsthat serve them, such as schools, churches, universities, theatres, museums, etc. The state is responsible for supporting efforts of different educational and cultural institutions. Classical political philosophers are convinced that only constant concern about all areas of the common good let us achieve peace and inner order, external peace, cultural and economic development, as well as it allows us to protect the repute and dignity of the state and the national and state interests.

Resignation of contemporary political philosophers from the concept of the common good is due to several reasons. The first one results from the departure from classical philosophy in general, and particularly from metaphysics and its language (human nature, the essence of the state and law). The concept of the common good has been removed as belonging to this philosophical tradition, incomprehensible and useless without it. It cannot also be easily reconciled with contemporary multicultural liberalism, modern (postmodern)democracy or individualism referring to eccentricity, since it connects with the traditional vision of society as a hierarchical structure and anindividual as subordinated the whole and stuck to principles. Moreover, at the end of the twentieth century there were also thinkers who showed the relationship between the ideal vision of happiness and good and the greatest crimes of humanity (critics of totalitarianism). The good has been discredited as hypocritical political substantiation and justification for paternalism and violence of "extremely vile regimes"4.

\section{THE RIGHTNESSOVERTHE CONCEPTIONS OF THE GOOD}

John Rawls - one of the most important political philosophers of thetwentieth century he laid down the rightnessof principles of justice before and over different conceptions of the good. The principles of justice define a basic shape of social structure. They are reasonable, it means that they can be brought before acourt of every citizen's reason and hedoes not find the grounds to reject them reasonably. The reason associated with impartiality and the principle of reciprocity causes that every thinking person can agree on them not falling into conflict with each other or with their professed beliefs (extensive doctrines). Every citizen will be able to accept them after thinking because he will perceive that they are associated with human (and therefore also his own) life chances. The principles of justice, allowing for affirmation of human dignity, are a fair basis for the cooperation and a sense of community with all the citizens (as no one is placedat the margins of social life).

Rawlscares about the differentiation between extensive doctrines under which various conceptions of the good are formulated the and principles of justice, which deliberately avoiding the issue of good, stop at the level of what is right. This distinction becomes the "foundation" of his political liberalism. Rightness of the principles of justice proposed by him is indifferent with respect to variousbroad doctrines conflicting with each other. What's more, this rightness allows for pluralism of various broad doctrines that can last, grow and compete with each other within and under the protection of a liberal and democratic state. Separation of numerous and diverse conceptions of the good from a right conception of justice is, on the one hand, to protect the principles of the liberal,

\footnotetext{
${ }^{4}$ See P. Śpiewak, W stronę wspólnego dobra, Aletheia, Warszawa 1998, p 6.
} 
democratic state from moving the conflicts regarding the hierarchy of goods into the political arena, on the other hand, to deliver a good, intelligent justification for the proposed principles. Rawls emphasizes that the disputes concerning what is the good have lasted for ages, while the political issues need to be solved in the predictivetime. You cannot postpone political decisions until a philosophical or moral issue is solved. The rightness is to be a kind of neutrality in the face of unsolved conflicts regarding the good. At the same time, it should be noted that the content of the principles of justice is moral, normative, therefore the rightness is not the result of their axiological neutrality.

Rawls says that a liberal society has the opportunity to exist on the condition that its members are reasonable and willing to see each other as free and equal (the principle of reciprocity). This state is only possible to maintain owing togeneral education. Thus, there is a serious problem. Education involves leading a man in the world of values and encouraging him/her to implement them, that is why it is an action of perfectionist nature oriented tothe particular good. However, the liberal state does not want to promote any conception of the good, which is expressed in its anti-perfectionism. This contradiction cannot be solved in any simple way.

Similar is the issue concerningliberal anti-paternalism that must be somehow reconciled with a rational concern about citizens, especially about those who are incapable of taking care of their own matters. Ajust state cannot allow for the situation that some citizens would die of hunger because of their helplessness. In this way it engages in paternalism, which we want to avoid. According to Rawls paternalistic intervention must be justified by the evident failure and absence of reason and will: and it must be guided by the principles of justices and what is known about the subject's more permanent aims and preferences, or by the account of primary goods ${ }^{5}$. The fact that as for the liberal state there areplenty of citizens that must be protected from their own irrational tendencies, is a significant problem. Ability to prevent this kind of dysfunction and pathology is essential for the fate of liberal democracy ${ }^{6}$.

It turns out that in certain situations and in certain ranges paternalism and perfectionism are unavoidable. They will always be associated with the promotion of some conceptions of the good, with the overall vision of what is in the interests of citizens and the state $^{7}$.It is not possible to be a perfect anti-perfectionist. You have to accept that anti-perfectionism of liberalism is not absolute and it is not able to be absolute. A just social order is a fundamental value and justice - the first virtue in a liberal society. A liberal state cannot resign fromelevating existed practices to the level of perfection, it must try to bring closer to "perfect" social relations. Liberal politics cannot avoid striving to realize a liberal vision of the state and society. Liberal ideals include for instance: the ideal of a just society, the ideal of a tolerant secular state, the ideal of the citizen who is

\footnotetext{
${ }^{5}$ J. Rawls, Teoria sprawiedliwości, transl. M. Panufnik i in., PWN, Warszawa 1994, p. 343. ${ }^{6}$ See W. Galston, Civic Education in the Liberal State, w: N. Rosenblum (ed.), Liberalismand the Moral Life, Harvard University Press, Cambridge, Massachusetts 1989, pp 89-102.

${ }^{7}$ Many authors believe that paternalism is a position which cannot be reconciled with liberalism, but at the same time they are willing to accept the so-called soft paternalism in situations when allowing people freedom of choice would lead to tragic consequences for all - see e.g. G. Dworkin, Paternalism, in: R. A. Wasserstorm (ed.), Morality and the Law, Wadsworth Pub. Co., Belmont, Cal. 1970, pp. 107-126; D. Husak, Paternalism and Autonomy, "Philosophy and Public Affairs," 1981, No. 10, pp. 27-46; J. Feinberg, Harm to Self, Oxford University Press, New York, 1986.
} 
entitled to the full rights, and who formulates his life plans rationally and independently, the ideal of equal treatment of all citizens, etc. The implementation of these ideals is being achieved by means of administrative procedures, education, tax politics etc. "Due to sterile conditions which are created in such institutions, due to demands that people exceeding their threshold renouncetheir subjective opinions, religious beliefs and interests, they may proceed in a manner similar to how the ideal impartial citizens might have proceeded or ideally neutral institutions in liberal system" ${ }^{\prime}$.Therefore, perfectionism turns out to be inevitable, despite the fact that neither particular moral doctrine nor philosophical conception of the good is imposed on citizens. Liberals, proving their antiperfectionism, would only point to the fact that liberalism does not need the implementation of a particular kind of widely understood good, but it allows for the implementation of a variety of purposes (goods) chosen individually; it does not enforce moral self-improvement of citizens, but it makes it possible giving them freedom. With regards to the discussion on anti-perfectionismof liberal democracy, antinomy cannot be avoided. Today, due to such intellectuals like Rawls and Habermas, liberal philosophy has got rid of hypocrisy which consists of accusing opponents of perfectionism and declaring anti-perfectionism ${ }^{9}$. Consistent anti-perfectionism is not only untenable as a theoretical problem; it is also socially undesirable and impossible to implement in practice. Social and state institutions must participate actively in shaping the liberal politics, which implies the use of perfectionistic strategy. The liberal state can be neither completely neutral nor consistently anti-paternalistic nor absolutely anti-perfectionistic.

The principles of justice, which have been indicated by Rawls, applies only to the basic social structure, and at the same time, they ensure that families, associations and churches can be governed by their internal laws. Therefore, there is a danger that the liberal state will preserve the areas of despotism. Despots can be heads of families, leaders of religious movements, presidents of associations, directors of companies, etc., and the violence(even it will be removed from the public sphere) will remain a permanent element of the private life. Rawls wants to avoid such an eventuality. He admits that considering" $A$ Theory of Justice",his opinion on the matter has not been stated quite clearly. That is why, in "The Law of Peoples" he formulates a clear opinion: "If the so-called private sphere is alleged to be a space exempt from justice, then there is no such thing" ${ }^{10}$. The liberal principles of political justice does not require that the decisions made in churches and families have been taken in accordance to democratic procedure. On the other hand, they impose major restrictions on churches and families - do not allow anyone to be treatedagainst the law. Although political principles do not apply directly to the inner life of churches and families, they still guarantee fundamental rights and freedoms and equal opportunities for all. As for the just state,there cannot be the areas removed from the control of law and constituting the enclaves of despotism ${ }^{11}$. Liberal democracy seeks to

\footnotetext{
${ }^{8}$ P. Przybysz, O pragmatycznym liberalizmie, „Transit - Przegląd Europejski” 1996, No. 2, p. 140.

${ }^{9}$ It was noticed by the authors such as Joseph Raz and Will Kymlicka - seeJ. Raz, TheMorality of Freedom, Clarendon Press, Oxford 1986, part II; W. Kymlicka, Liberalism, Community, and Culture, Oxford University Press, Oxford, New York 1989.

${ }^{10}$ J. Rawls, Prawoludów, transl. by M. Kozłowski, Aletheia, Warszawa 2001, s. 229 or J. Rawls The Law of People, Harward University of Press 1999, p. 161.

${ }^{11}$ See A. Gutmann, Demokracja, in: R.E. Goodin, Ph. Pettit (edit.), Przewodnik po wspótczesnej filozofii politycznej, translated by C. Cieśliński, M. Poręba, KiW, Warszawa 1998, pp. 536-538.
} 
ensure the equality of citizens and protects the weak against despotism and tyranny of the stronger, hence itrecognizes the equality under the law and freedom from the tyranny as a kind of the good worth implementing.

There is no escape from the question of the good (and the bad) while considering the social and political issues, which are moral issues in some important sense for us. However, the defence of the principles of justice by means of pointing out theirrightness and distinguishing them from various conceptions of the good is - at the level of politic and political philosophy - reasonable and purposeful because of the values that we cherish together as well as in order to avoid certain damages which we fear. The separation of the justice from ethical issues is also justified due to the restrictions of the public reason (in particular the impossibility of carrying out the justifications in politics from the position of the whole truth), which we cannot ignore. Rawls defends his conceptionsin other ways - for example, he points to its practical values (but not ideological and philosophical), its correlation with our moral intuitions or our understanding of ourselves. A great part of his argumentation takes a pragmatic and utilitarian shape/character. The theory of justice and political liberalism in the form proposed by him are simply better than other theories regarding social life because they generate much less misery, suffering and violence. Arguments of utilitarian nature show that a reasonable benefit can be received when we adopt fair rules (it has nothing to do with the acceptance of the doctrine of utilitarianism as a vast philosophical doctrine). Rawls admits that elements of utilitarianism are inevitable in political philosophy - we cannot ignore the fact that something is better, more beneficial and more valuable to us.

A common understanding of justice as fairness makes a constitutional democracy ${ }^{12}$. Rawls is not only interested in the reasons to be obligatory but also the conditions of their social and political acceptance, because he notices the fact that the direct motive of our actions can be abenefit or a habit but not the rightness of some standards and our belief that it should be applied. Habermascomes into conclusion that this was an old problem "how the rational project of a just society, in abstract contrast to an obtuse reality, can be realized after confidence in the dialectic of reason and revolution, played out by Hegel and Marx as a philosophy of history, has been exhausted-and only the reformist path of trial and error remains both practically available and morally reasonable"13. Since the most common motives of our actions are habits, feelings, interests and needs, they should be treated with great seriousness when considering political issues. Rawls emphasizes that representatives of different overall visions of the world, even remaining in conflict, they can agree to a liberal conception of justice and democracy, because it is beneficial and consistent with the interests and feelings of all. There are two things that are needed to arise the idea of rational benefits: first of all, it is a fact that citizens, despite different views, have the same political conception of themselves as free and equal persons; secondly, it is a fact that even though their conceptions of the good may be different in the content, they include the same set of basic goods. What are the reasons of people's action in the appropriate manner - whether they are guided by the conviction of the rightness of principles, or they just desire to realise some interests - it may be their secret and politics has no intention of exploring it. However, Rawls assumes that citizens who are

${ }^{12}$ J. Rawls, Teoria sprawiedliwości, p. 333 or J. Rawls, A Theory of Justice, p. 214.

${ }^{13}$ J. Habermas, Faktyczność i obowiazywanie, transl. by A. Romaniuk, R. Marszałek, Scholar, Warszawa 2005, p. 72 or J. Habermas, BetweenFacts and Norms, transl. by William Rehg, p. 57. 
guidedinitially by self-interest only, after a whilethey will be able to recognize the rightness of existing principles in the liberal state (recognition of good reasons) .

The issue regarding the acceptance of the principles of justice is concerned with the problem of stability of the liberal state. This stability is based on respect and acceptance of the principles of justice. Thebest situation is when this acceptance is achieved owing to good reasons, that is, by means of recognizing its rightness, not only their instrumental utility for their own purposes. According to Habermas, Rawls in A Theory of Justice is trying to carry out the proof of congruence of the right and the good ${ }^{14}$. He shows that just institutions create the conditions,for the sake of people's good interests, in which their own freely chosen life plans are realised in the same conditions granted to anybody.Considering a well-ordered society, it is beneficial to satisfy the demands of justice every time and for everyone. "The self-stabilization of a well-ordered society is therefore based not on the coercive force of law but on the socializing force of a life under just institutions, for such a life simultaneously develops and reinforces the citizens' dispositions to justice" ${ }^{15}$.

\section{A THIN CONCEPTION OF THE GOOD}

Rawls claims that the principles of justice are primary and independent with respect to any conception of the good and that they have a rational, universal and neutral character. However, the meanings of these concepts have been somewhat modified by Rawls. Neutrality denotes a lack of coercion and not imposing any particular conception of the good on anyone; rejection of the belief in the existence of "natural" superiority or inferiority of certain conceptions of a good life; universality means only that "the content does not deter anyone from standing up for neitherside"16; and rationality lies in the fact that the comprehension of individuals is their only source. The concepts of the good are potential source of endless conflict; it is not possible to gain rational consent, therefore the discussions on it should be removed from the sphere of political life. The liberal state does not impose religious belief on anyone or does not arrange social lifeaccording to some transcendent standards and this is its neutrality ${ }^{17}$. Rawls maintains that his theory meets both criteria of a deontological moral theory and a teleological one. "Thus, heassumes that the first one presumes that what is right does not depend on what is good, and the second one maintains that what is right is good"18. According to Rawls, the purpose of the state may not be the maximization of any specific public good. That is what his theory differs from other political theories - such as the utilitarian theory of Locke's and Bentham's, where the priority should be assigned to the concept of the common good. No concept of the good cannot be regarded as more important than justice, and rights cannot be deprive from individuals due to some other individual or collective goods. The rights of

\footnotetext{
${ }^{14}$ Ibidem, p.73 or ibidem p. 58

${ }^{15}$ Ibidem. It is possible only if the just institutions already exist, but it does not allow for the establishment of principles of justice in the society which are not familiar.

${ }^{16}$ A. Chmielewski, Kontraktualizm i jego krytyka, „Kwartalnik Filozoficzny” 1998, vol. XXVI, part 4, p. 73

${ }^{17}$ The problem of liberal neutrality intoduced by Rawls is widely discussed by T. Buksiński in his workWspółczesnefilozofiepolityki, Wydawnictwo IF UAM, Poznań 2006, p. 51-55.

${ }^{18}$ Z. Rau, Liberalizm. Zarys myśli politycznej XIX i XX wieku, Aletheia, Warszawa 2000, p. 99.
} 
individuals and the principles of justice can be derived without reference to any concept of what is good; without assuming a certain conception of morality.

Rawls tries to go beyond a particular cultural context and be animpartial thinker. As a result of proposed social agreement, it is expected to create a society as much neutral as possible when the attitudes towards different lifestyles and individual choices are considered. The conception of justice as fairness emphasizes suchnature of the state. Chmielewski says that: "The essence of the requirement of neutrality of the state is the belief that there is no concern of a state or society that people can make good choices, but they are able to have the freedom to make their own choices which are led by their personal notion of what is good" ${ }^{19}$.Furthermore, we can read that it is a way of expressing a philosophical belief that no one (including the state or society as a whole) is not an absolute, infallible and unquestionable moral authority ${ }^{20}$. The theory of justice is not a philosophical materialization of any conception of the good, in fact it keeps - or at least trying to keep - neutrality in relation to the individual conception of the good, and its aim is to develop social ground, allowing everybody to achieve various ideas, goals and plans. Therefore, the neutrality and theoretical abstractness of the conception of justice is a condition allowing for the domestication of the differences between individual conceptions of morality, which means among other things, prevention from the imposition of such individual moral ideals to others ${ }^{21}$.

According to Rawls, the state should provide such a social order that it would allow citizens to develop individual conceptions of the good. However, this conviction is a kind of conception of the good, of which Rawls is well aware. For this reason, the concern of the liberal state that everyone could realize his conception of the good is proposed to be called thethin theory of the good ${ }^{22}$. Such understood thin conception of the good opposes broad conceptions emerging from the extensive and overall philosophical, moral and religious doctrines. The thin conception consists of the goods of a political nature, such as fundamental rights, freedoms and opportunities; basic resources (income, wealth) allowing for achieving freely stated objectives and so-called social foundations of selfrespect $^{23}$.

It is possible to say that the neutrality of principles considering liberal justice of democracy lies only innot imposing any particular conception of the good (non arbitrariness) onanyone, due to the fact that it could not be justified to the general public, and imposing it by the means of violence would shatter the liberal democracy itself.

\footnotetext{
${ }^{19}$ A. Chmielewski, Kontraktualizm i jego krytyka, p. 61.

${ }^{20}$ Ibidem. Opponents of Rawls (mainly communitarians) show, on the other hand, that the pursuit of such a sense of neutrality and impartiality are nothing like the best evidence of a strong commitment to specific (western) culture. In this way, they present as the classic problem of antinomy.

${ }^{21}$ A. Chmielewski, Kontraktualizm i jego krytyka, p. 62.

${ }^{22}$ J. Rawls, Teoriasprawiedliwości, p. 543-548 or J. Rawls, A Theory of Justice, p. 348-350.

${ }^{23}$ A chief opponent of neutralityof liberalism is Galston. He believes that Rawls is one of the most important contemporary defenders of neutrality, who bases his convictions on false arguments coming from skepticism and lexical priority of liberty - see. W. Galston, Celeliberalizmu, p. 100. Neutralistic liberalism of Rawls is also analyzed and criticized by VinitHaksar in Equality, Liberty, and Perfectionism, Oxford University Press, Oxford 1979. Perhaps the unambiguous interpretation of Rawls as a supporter of neutralistic liberalism was a direct response to The Theory of Justice. Knowledge of the later works of this author allows us to read his previous thoughts in a slightly different way.
} 
However, it must be stressed, that not imposing any particular conception of the good is not tantamount to consent to any conception. In a liberal democracy certain lifestyles and behaviours are excluded, and conceptions of the good, clearly inconsistent with accepted principles of justice, cannot count on the respect and approval. In such cases, liberal democracy is not and cannot be neutral, but it must be a state of at least minimally involved $^{24}$

The political conception of justice deals with issues regarding what is morally right and wrong; it is a moral idea, specifying the moral values associated with the functioning of the state and society. Political philosophy is not exclusively descriptive, and perceiving political issues is not determined by how political relations are currently shaped. Criticism of the current political situation is always possible. If we limit the politicalto the historically changing ways of doing politics, and change political philosophy into the only descriptive science, then the criticism would turn out to be impossible. "We must hold fast to the idea of the political as a fundamental category and covering political conceptions of justice as intrinsic moral values" 25 - says Rawls. Since moral values are considered in politics, it cannot ever take a neutral character (axiologically). Speaking of the neutrality of liberal politics with respect to morality makes sense only if we want to emphasize that the moral virtues and merits of the citizens are not something that the state awards by the use of conferring honours and positions. Not distinguishing these issues is the cause of endless discussions about neutrality and unneutrality of liberalism.

The thin conception of the good allows us to maintain the stability of a liberal state. The stability is crucial for any society. Traditionally, it was believed that it is able to be achieved only by the use of common broad, comprehensiveconception of the good. Rawls takes the opposite view. "Therefore, one can say that, according to Rawls, people instead of agreeing on a particular conception of the good, they should rather take care of creating the conditions for its free determination and revision. These conditions are specified by the principle of justice as fairness" ${ }^{26}$. The stability of a liberal society lies in the ability to promote a right conception of justice, which is a thin conception of the good. It favours the formation of a sense of justice and sensitivity to injustice, which in turn allows us to resist various destructive factors in the state. Just law and well-functioning social institutions never contribute to bad inclinations and they do not encourage immoral behaviour, but they make that the successive generations of citizens acquire a sense of justice and recognize that everyone benefits from obeying the law. That is why, a just society is stable, because it promotes the good of its members (but not a specific conception of the good), which is justice.

Rawls says, "Thus we may suppose that there is a morality of association in which the members of society view one another as equals, as friends and associates, joined together in a system of cooperation known to be for the advantage of all and governed by a

\footnotetext{
${ }^{24}$ The fact that liberalism is not and cannot be neutral is claimed by Stanley Fish argues in his essay Liberalism Doesn't Exist, in: idem, There Is No Such Thing as Free Speech And It's a Good Thing To, Oxford University Press, New York, Oxford 1994, pp. 134-140. Fish emphasizes that the liberals are always one of the parties in the debate and they fight for their right with a commitment that is incompatible with the ideal of neutrality.

${ }^{25}$ J. Rawls, Prawoludów, op. cit., p. 248 orJ Rawls, The Law of Peoples, op. cit., p. 174.

${ }^{26}$ A. Szahaj, Jednostka czy wspólnota? Spór liberatów z komunitarystami a ,, sprawa polska”, Aletheia, Warszawa 2000, p. 14.
} 
common conception of justice. The content of this morality is characterized by the cooperative virtues: those of justice and fairness, fidelity and trust, integrity and impartiality. The typical vices are graspingness and unfairness, dishonesty and deceit, prejudice and bias" ${ }^{27}$.Rawls, describing social relations, uses the notion of civic friendship ${ }^{28}$ that flourishes under the protection of just rules of social life. "Thus justice is the virtue of practices where there are competing interests and where persons feel entitled to press their rights on each other"29. People in post-traditional societies have multiple, often contradictory ideas about the good and this is why justice including the idea of equal rights must be regarded as a superior value and a virtue of justice as the most important in the political order. Justice is the best guarantee of stability, because it equally divides the freedom and the right to achieve individual goals, and freedom is the most valued good.

Rawls emphasizes that his version of liberalism is not a form of enlightenment liberalism, which is anoverall, broad, liberal, secular philosophical doctrine. Liberal doctrines were founded on a particular philosophical conception of the reason and a man, and they were appropriate for the modern period, when Christianity began to lose its authority. Political liberalism of Rawls does not have any goals beyond the politics. $\mathrm{He}$ takes the reasonable pluralism of overall, extensive, imperative doctrines, among which there are illiberal and religious doctrines. The purpose of political liberalism is not a fight against such doctrines, but to develop such concept of justice at which this diversity could freely last. Rawls hopes that the area of fundamental principles of political life can be (and already is) an area of consensus, in which various extensive doctrines overlap each other and in this sense they support each other (and not fight) and assure of their rationality.

Although the political concept of justice is a normative system, the basic/fundamental ideas occurring there cannot be analyzed by reference to the metaphysical category. No philosophy or religion, grasping the truth about the metaphysical order of being, are unable to provide a real common basis for a political life in liberal and democratic society in which pluralism is a fact. Political philosophy must reckon with this fact and try to determine what may be the subject of the consent and agreement with regard to moral and political issues; which can assure the unity in spite of diversity; which can guarantee the societycomposed of people as they are (and not who they could or should be), the continuance and development. It is a pragmatic approach in the best sense of the word, free from naive optimism, but also not infected with excessive scepticism. If we can learn the specific normative system and use it to describe our state and society, as well as to consider our social and political problems, it is(according to Rawls) completely enough to accept the system and get rid of persistent efforts to demonstrate its truthfulness.

\section{THE POLITICAL CULTURE OF CITIZENS OF LIBERAL} DEMOCRACY

Habermas emphasizes that the liberal state and all developed rights and procedures are left ultimately on an ethos, a political culture from which they derive lifetime, but over which they do not take control,and which they do not produce. "The political system based on the principle of lawfulness is not a closed circuit, but it is also left on the

\footnotetext{
${ }^{27}$ J. Rawls, Teoriasprawiedliwości, op. cit., p. 640 or J. Rawls, A Theory of Justice, p. 413

${ }^{28}$ Ibidem, p. 701 or p. 454.

${ }^{29}$ Ibidem, p. 183 or p. 112 .
} 
libertarian political culture and the society accustomed to freedom" ${ }^{30}$. Politics and the law must always be open to certain sources of legitimacy, which they does not dispose of; they must remain in intimate relationship with the world of life, due to the fact that only then they are able to confront and solve real problems ${ }^{31}$. The structure and functioning of modern liberal democracy,in a sense, "take off " from the citizens moral responsibilities and they do not place their hopes in their virtues moving everything to the formal procedures. In this way they cause that citizens, regardless of their intrinsic motivation, behave as if they were equipped with the rare qualities of spirit. However, their actual cooperation is always carried out or breaks down in relation to the broader context, which constitute the world of life together with a whole range of values and opinions of an axiological nature. Democratic procedures do not work in a vacuum. Therefore, to some extent, it is possible to demand anorientation to the common good from the citizens, but it cannot be made a legal obligation ${ }^{32}$. Citizens' involvement on the side of freedom and democracy is necessary in order to the liberal-democratic order could exist, but it cannot be legally ordered and forced into it. This involvement in public affairs and taking part (reachingan agreement) in the discussion considering the rules of cooperation give the legitimizing power to any political decisions. The political culture of citizens should predispose them not to stay the players who are closed for the free market in their selfishness, but to use their political freedom and strive for agreement regarding the issues relevant for all. It is a manifestation of reasonableness, which turns out to be an important political virtue.

Habermas, like Rawls shows how a liberal and democratic state replaces required virtues with the presumption of reasonableness of citizens, and - just like Rawls (and in opposition to the republican tradition) - he moves a burden of justification of the causative power considering practical reason from the mentality of individuals to (deliberative) procedures. The democracy is based on the reasonable "communication device" and not the competence of the actors. However, the normative content does not evaporate from the principles of political life, but it is retained - the primary concern of the state is the sake of justice, fairness, equality, etc.

Habermasadmits that the questions of the normative content are always asked by the people who already have a specific vision of the world and themselves - we are discussing having formed the horizon. However, are we able to give a binding answer to these questions from inside the horizon? Habermas is concerned that such an attempt would result in a lack of considering others, the strangers. He believes that there is a fundamental difference between the question of what is good for me and for us, understood as relatives or friends (who identify with this same concept of the good), and the question of what is right for everyone, that is, for us and for those who are quite alien to us. As forHabermas, the priority of the right over the good results from the logic of progressive broadening the horizon. Starting from their own interpretation of the world and themselves, constantly learning from each other, the parties reach common ground - finding a political point of view $^{33}$. This is a difference from each other of particularistic ethical horizons and common, moral, balanced, just conditions of political discourse. It is a common,

\footnotetext{
${ }^{30}$ J. Habermas, Uwzględniajac innego, translated by A. Romaniuk, PWN, Warszawa 2009, p. 265.

${ }^{31}$ J. Habermas, Faktyczność i obowiazywanie, op. cit., p. 146.

${ }^{32}$ J. Habermas, Uwzględniajac innego, p. 265.

${ }^{33}$ J. Habermas, Uwzględniając innego, pp. 268-269.
} 
reasonable morality which is the foundation of a liberal political culture maintaining the consciousness of citizens in a pluralistic postmodern society. In modernsocieties which are increasingly complex and pluralistic, more and more trust for others (such as experts in the fields we do not know)is needed, which cannot be reduced to the intellectual requirement of abstraction (abstracting from the difference). The common morality (which is not only functional overlappingof different lifestyles) is essential, but it is still in danger and fragile.

Some authors (e.g., McCarty and Bernstein) emphasize the dialectical nature oflinking the good and the right in contemporary politics. They say that the question considering what is good for me is closely linked to the issue of what is good for others. Selfcomprehension and a vision of society are just two aspects of the same problem, which is expressed in the question, what is the good life. These two aspects can be separated from each other only analytically, but in practice they remain undifferentiated. The right and the good are constantly overlapping, as well as an individual identity is intertwined with the collective identity (as an individualization occurs in the course of socialization). It is impossible to separate the issue of justice from what is ethical because it is impossible to say what is just without the knowledge of what is good ${ }^{34}$. Habermasis afraid thatapproving of such dialectical linkage of the good and the right may withdraw our comprehension of the political sphere to the concept of Carl Schmitt. Then the politics would mean no more than distinguishing enemies from friends and striving for dominance over enemies. The peace would be only temporary suppression of the violence due to the fear of the power of the enemy; sometimes to consolidate their forces and to estimate the enemy's forces. Parties that are unable to distance themselves for their own ethical horizon, will never be able to assume that they may be wrong, they will neither believe in reasonable political solutions of problems nor the rational arguments that would achieve consensus.

The politics understood as deliberation makes sense only on the assumption that we can persuade each other by means of arguments, and learn from one another. Without anticipating (even only in imagination) reasonable solution of the problem based on the argumentation, no dispute can take place because the parties would not know what they want to achieve; there would also be no reasons for any decision to be considered legitimate. The political culture of citizens of liberal democracy allows for such anticipation. It allows us to transfer from we, based on a common understanding of what is good, to we as those who differ from one anotherin important matters, but despite this they can live together without hostility, based on the principles of law which in turn they are trying to reflect respect in their formulas for the individual and cultural diversity. The political culture of citizens causes them to consider the politics (perceived as a skill of continuous expressing opinions and taking into account both cultural differences and universal rights of individuals) to be better than the politics of aversion to strangers; better - therefore good for our political, abstract, reasonable we, which perceives that public space cannot be appropriated by one tribe or built for one generation ${ }^{35}$.

\footnotetext{
${ }^{34}$ SeeTh. McCarty, Ideals and Illusions, Cambridge Mass., 1991, p. 192.

${ }^{35}$ Compare H. Arendt, Kondycja ludzka, transl. by A Lagodzka, Aletheia, Warszawa 2000, p. 61.
} 


\section{REFERENCES:}

[1] Arendt H., Kondycja ludzka, transl. by A Łagodzka, Aletheia, Warszawa 2000.

[2] Buksiński T., Współczesne filozofie polityki, Wydawnictwo IF UAM, Poznań 2006.

[3] Chmielewski A., Kontraktualizm i jego krytyka, „Kwartalnik Filozoficzny” 1998, vol. XXVI, part 4.

[4] Dworkin G., Paternalism, in: R. A. Wasserstorm (ed.), Morality and the Law, Wadsworth Pub. Co., Belmont, Cal. 1970.

[5] Galston W., Civic Education in the Liberal State, w: N. Rosenblum (ed.), Liberalismand the Moral Life, Harvard University Press, Cambridge, Massachusetts 1989.

[6] Gutmann A., Demokracja, in: R.E. Goodin, Ph. Pettit (edit.), Przewodnik po wspólczesnej filozofii politycznej, translated by C. Cieśliński, M. Poręba, KiW, Warszawa 1998.

[7] Habermas J., BetweenFacts and Norms, transl. by William Rehg.

[8] Habermas J., Faktyczność i obowiązywanie, transl. by A. Romaniuk, R. Marszałek, Scholar, Warszawa 2005.

[9] Habermas J., Uwzględniając innego, PWN, Warszawa 2009.

[10] Husak D., Paternalism and Autonomy, "Philosophy and Public Affairs," 1981, No. 10, J. Feinberg, Harm to Self, Oxford University Press, New York, 1986.

[11] Koperek J., Dobro wspólne, in: B. Szlachta (edit.), Stownik spoteczny, WAM, Kraków 2004.

[12] Krucina J., Dobro wspólne, in: Encyklopedia katolicka, vol. III, TN KUL, Lublin 1985.

[13] McCarty Th., Ideals and Illusions, Cambridge Mass., 1991.

[14] Przybysz P., O pragmatycznym liberalizmie, „Transit - Przegląd Europejski” 1996, No. 2.

[15] Rau Z., Liberalizm. Zarys myśli politycznej XIX i XX wieku, Aletheia, Warszawa 2000.

[16] Rawls J., Prawoludów, transl. by M. Kozłowski, Aletheia, Warszawa 2001.

[17] Rawls J., Teoria sprawiedliwości, transl. M. Panufnik i in., PWN, Warszawa 1994.

[18] Rawls J., The Law of People, Harward University of Press 1999.

[19] Raz J., TheMorality of Freedom, Clarendon Press, Oxford 1986, part II; W. Kymlicka, Liberalism, Community, and Culture, Oxford University Press, Oxford, New York 1989.

[20] Szahaj A., Jednostka czy wspólnota? Spór liberałów z komunitarystami a ,sprawa polska", Aletheia, Warszawa 2000.

[21] Śpiewak P., W stronę wspólnego dobra, Aletheia, Warszawa 1998.

\section{SŁUSZNOŚĆ ZASAD JAKO POJECIE DOBRA}

Artykuł mówi o zmierzchu idei dobra wspólnego oraz o wyniesieniu idei sprawiedliwości ponad wszelkie koncepcje dobra. J. Rawls rozróżnia rozległe doktryny, z których wynikają rozmaite koncepcje dobra, od zasad sprawiedliwości, które tak są formułowane by uniknąć kwestii dobra a zatrzymać się na poziomie tego, co prawe i właściwe. Sprawiedliwość pozwala na pluralizm rozmaitych rozległych doktryn, które mogą trwać, rozwijać się i konkurować ze sobą pod ochroną liberalnego i demokratycznego państwa. Musimy jednak zauważyć, że tam gdzie w grę wchodzą problemy społeczne i polityczne nie uciekniemy przed kwestią dobra (i zła), gdyż problemy te mają charakter moralny w istotnym dla nas sensie. Obrona zasad sprawiedliwości przez wskazanie na ich poprawność i odróżnienie ich od różnych koncepcji dobra jest na poziomie polityki i filozofii polityki jak najbardziej rozsądna i celowa (ze względu na wartości, które podzielamy oraz ze względu na szkody, których staramy się uniknąć), nie zmienia to jednak faktu, że nadal poruszmy się $\mathrm{w}$ obrębie koncepcji dobra. Stabilność liberalnego 
społeczeństwa zależy od jego zdolności promowania określonej koncepcji sprawiedliwości, którą scharakteryzować można jako wąską koncepcje dobra. Normatywna treść nie wyparowuje z życia politycznego ale pozostaje w nim w postaci zasad sprawiedliwości, bezstronności, równości itd.

Słowa kluczowe: sprawiedliwość, dobro, J. Rawls.

DOI:10.7862/rz.2016.hss.15

Przesłano do redakcji: styczeń 2016

Przyjęto do druku: marzec 2016 